et $a l,{ }^{1}$ which is the only other of this kind to have tried to disentangle the effects of nicotine yield and tar yield. These results suggest that non-pharmacological factors such as the taste or flavour of the tobacco smoke-of which tar yield is believed to be the major determinant-may be as important as nicotine in influencing how a cigarette is smoked. The "oversmoking" of cigarettes with low tar and nicotine yields, which has been consistently observed in previous studies, may be partly due to this tendency to compensate for the lower delivery of tar. If corroborated (and clearly more studies that separate the effects of nicotine and tar yield are needed) these findings would have discouraging implications for the design of a "safer" cigarette- that is, one that by virtue of its yields and other design features would be smoked in a way that was both safer and acceptable to the smoker. If the maintenance of an adequate intake of tar, which is known to be responsible for the increased risk of lung cancer and chronic bronchitis among smokers, turns out to be one of the main motives for smoking, then the task of developing a cigarette that is acceptable to smokers and at the same time less harmful to their health will be much more difficult.

We thank our colleagues at the Addiction Research Unit and Dr Ray Thornton, British-American Tobacco Co Ltd, for their helpful comments, Gillian Woolcock for secretarial help, the Medical Research Council for financial support, and British-American Tobacco Co Ltd for loaning us the puff analyser and providing other technical help.

\section{References}

1 Russell MAH, Jarvis MJ, Iyer R, Feyerabend C. Relation of nicotine yield of cigarettes to blood nicotine concentrations in smokers. $\mathrm{Br} \mathrm{Med} \mathfrak{F}$ 1980;280:972-6.

2 Wald N, Howard S, Smith PG, Bailey A. Inhaling habits among smokers of different types of cigarette. Thorax $1980 ; 35: 925-8$.

3 Creighton DE, Noble MJ, Whewell RT. A portable smoking pattern recorder. Biotelem Patient Monit 1979;6:186-91.

4 Russell MAH, Cole PV, Brown E. Absorption by non-smokers of carbon monoxide from room-air polluted by tobacco smoke. Lancet 1973; : $576-9$.

5 Feyerabend C, Russell MAH. Improved gas-chromatographic method and micro-extraction technique for the measurement of nicotine in biological fluids. F Pharm Pharmacol 1979;31:73-6.

6 Kenny DA. Correlation and causality. New York: Wiley, 1979.

7 Sutton SR. Fear-arousing communications and health-related behaviours: a decision-making approach. London: University of London, 1981. (PhD thesis.)

${ }^{8}$ Goldfarb T, Gritz ER, Jarvik ME, Stolerman IP. Reactions to cigarettes as a function of nicotine and "tar." Clin Pharmacol Ther 1976;19:767-72.

(Accepted 9 fuly 1982)

\title{
Mesotheliomas and asbestos type in asbestos textile workers: a study of lung contents
}

\author{
J C WAGNER, G BERRY, F D POOLEY
}

\begin{abstract}
The asbestos contents of the lungs of former employees of an asbestos textile factory were determined at necropsy using a transmission electron microscope. Those who had died of mesothelioma were compared with a matched sample of those who had died of other causes. The predominant fibre processed in the factory was chrysotile, but crocidolite had also been used. The lung content was consistent with the known exposure to chrysotile, but the crocidolite content was also high, being about 300 times that of the general population of the United Kingdom. The lungs of those with mesothelioma did not contain more of either chrysotile or crocidolite than the lungs of the controls, so no particular type of asbestos could be implicated in causing the mesotheliomas.

The evidence of substantial exposure to crocidolite means that the mesotheliomas that occurred in this factory could not be attributed with any certainty to the exposure to chrysotile.
\end{abstract}

MRC Pneumoconiosis Unit, Llandough Hospital, Penarth, South Glamorgan

J C WAGNER, MD, FRCPATH, senior member of scientific staff (clinical) G BERRY, MA, statistician (present appointment: senior lecturer, Commonwealth Institute of Health, University of Sydney, NSW, Australia)

Department of Mineral Exploitation, University College, Cardiff F D POOLEY, DPHIL, reader

\section{Introduction}

The mortality and morbidity of workers in an asbestos textile factory in the north of England have been studied for more than 25 years. ${ }^{1-8}$ The type of asbestos used in the factory was predominantly chrysotile; crocidolite asbestos was also used, ${ }^{2} 3578$ but exposure to it was considered to have been unimportant compared with exposure to chrysotile. The British Occupational Hygiene Society used data from this factory in determining its hygiene standard ${ }^{6}$ for chrysotile, and Peto $^{59}$ attributed mesotheliomas occurring in this factory to exposure to chrysotile. The association between crocidolite and mesothelioma, however, is well established while the evidence implicating chrysotile is much weaker. Exposure to crocidolite in the factory cannot be measured either for individual workers or for groups of workers, although between 1931 and 1970 an average of about 60 tonnes of crocidolite was processed a year. ${ }^{10}$ Therefore, we carried out a study on postmortem material to determine the amounts of the different types of asbestos in the lungs of former workers at the factory.

\section{Patients and methods}

Postmortem material was available for 103 patients $(83$ men and 20 women) who had worked at the asbestos textile factory and had died in the period 1964-75 and for whom a coroner's postmortem examination had been carried out at the local hospital. In each case several histological blocks from the lung were available, and the sex, age at death, year of death, cause of death, and length of service at the factory were noted. Thirteen deaths had been due to pleural mesothelioma (11 men, two women). Mesothelioma was diagnosed initially by the pathologist at Rochdale and later confirmed by the 
TABLE I-Details of 12 patients who died of mesothelioma in study of lung contents

\begin{tabular}{|c|c|c|c|c|c|c|c|}
\hline $\begin{array}{l}\text { Case } \\
\text { No }\end{array}$ & Sex & $\begin{array}{l}\text { Year first } \\
\text { exposed }\end{array}$ & $\begin{array}{l}\text { Year of } \\
\text { death }\end{array}$ & $\begin{array}{c}\text { Age at } \\
\text { death (years) }\end{array}$ & $\begin{array}{c}\text { Latent } \\
\text { period (years)* }\end{array}$ & $\begin{array}{c}\text { Length } \\
\text { of service (years) }\end{array}$ & Jobs in factory \\
\hline $\begin{array}{r}1 \\
2 \\
3 \\
4 \\
5 \\
6 \\
7 \\
8 \\
9 \\
10 \\
11 \\
12\end{array}$ & $\begin{array}{l}M \\
F \\
M \\
M \\
M \\
M \\
M \\
M \\
M \\
M \\
M \\
F\end{array}$ & $\begin{array}{l}1923 \\
1924 \\
1929 \\
1937 \\
1940 \\
1943 \\
1927 \\
1918 \\
1925 \\
1939 \\
1922 \\
1962\end{array}$ & $\begin{array}{l}1968 \\
1969 \\
1970 \\
1970 \\
1970 \\
1970 \\
1972 \\
1973 \\
1974 \\
1974 \\
1964 \\
1972\end{array}$ & $\begin{array}{l}59 \\
59 \\
60 \\
50 \\
62 \\
47 \\
67 \\
72 \\
66 \\
66 \\
57 \\
64\end{array}$ & $\begin{array}{l}45 \\
45 \\
41 \\
33 \\
30 \\
27 \\
45 \\
55 \\
48 \\
35 \\
43 \\
10\end{array}$ & $\begin{array}{r}45 \\
24 \\
16 \\
26 \\
30 \\
3 \\
40 \\
43 \\
36 \\
12 \\
37 \\
10\end{array}$ & $\begin{array}{l}\text { Cheese winding, carding, spinning, interdoubling } \\
\text { Spinning } \\
\text { Moulded goods, brake-band lining finishing, rubbcr shed } \\
\text { Bag carrier in subsidiary factory (16 years), in warehouse (10 years) } \\
\text { Disintegrating asbestos in subsidiary factory (19 years), in garage } \\
\text { Doubling and winding } \\
\text { Weaving brake-band lining ( } 29 \text { years), cut joints (11 years) } \\
\text { Spinning } \\
\text { Weaving ( } 32 \text { years), proofed goods (four years) } \\
\text { Carding, spinning, and interdoubling } \\
\text { Card room (one year), proofed goods ( } 15 \text { years), in warehouse (21 years) } \\
\text { Part-time office cleaner }\end{array}$ \\
\hline
\end{tabular}

*Period from first exposure to death.

TABLE II-Details of lung contents of those dying of mesothelioma and controls (fibre counts expressed in millions $/ g$ )

\begin{tabular}{|c|c|c|c|c|c|c|c|}
\hline $\begin{array}{c}\text { Case } \\
\text { No }\end{array}$ & Chrysotile & Crocidolite & Tremolite & Amosite & Anthophyllite & $\begin{array}{c}\text { Total } \\
\text { asbestos }\end{array}$ & $\begin{array}{l}\text { Other } \\
\text { s fibres }\end{array}$ \\
\hline \multicolumn{8}{|c|}{ Subjects dying of mesothelioma } \\
\hline 1 & $77 \cdot 6$ & $277 \cdot 3$ & & 18.5 & \multirow{8}{*}{$0 \cdot 1$} & \multirow{13}{*}{$\begin{array}{r}373 \cdot 4 \\
475.2 \\
55.8 \\
13.9 \\
33.0 \\
44 \cdot 7 \\
109.3 \\
116.7 \\
47 \cdot 8 \\
22.7 \\
160.9 \\
350.5 \\
224 \cdot 1 \\
30.3 \\
34.2 \\
29.7\end{array}$} & \multirow{8}{*}{$\begin{array}{r}11.1 \\
7.2 \\
3.6 \\
2.7 \\
25.4 \\
4.8 \\
11.7 \\
6.9 \\
1.2 \\
2.5\end{array}$} \\
\hline 2 & $\begin{array}{r}48 \cdot 0 \\
6 \cdot 7\end{array}$ & 393.6 & $24 \cdot 0$ & $9 \cdot 6$ & & & \\
\hline 3 & 12.4 & $\begin{array}{r}40.1 \\
1.2\end{array}$ & & 0.1 & & & \\
\hline 3 & 19.5 & 1.8 & $1 \cdot 2$ & 10.6 & & & \\
\hline 4 & $\left\{\begin{array}{l}21 \cdot 4 \\
42 \cdot 9\end{array}\right.$ & $19 \cdot 5$ & $1 \cdot 4$ & $2 \cdot 4$ & & & \\
\hline & $\begin{array}{l}42 \cdot 9 \\
90 \cdot 4\end{array}$ & $\begin{array}{l}57 \cdot 2 \\
25 \cdot 2\end{array}$ & 3.5 & $\begin{array}{l}5 \cdot 2 \\
1 \cdot 1\end{array}$ & & & \\
\hline 5 & 36.9 & 8.6 & $1 \cdot 7$ & 0.6 & & & \\
\hline 6 & $\begin{array}{l}17 \cdot 2 \\
16 \cdot 9\end{array}$ & $\begin{array}{r}4.5 \\
130.7\end{array}$ & $0 \cdot 2$ & 0.9 & & & \\
\hline 8 & 218.6 & 86.6 & 28.9 & 16.5 & & & \multirow{5}{*}{$\begin{array}{r}111.3 \\
59.8 \\
7.5 \\
6.3 \\
14.9\end{array}$} \\
\hline 9 & 22.4 & 191.8 & & $10 \cdot 0$ & & & \\
\hline 10 & 25.9 & 0.7 & $2 \cdot 7$ & 1.0 & & & \\
\hline 11 & $24 \cdot 1$ & $7 \cdot 0$ & $2 \cdot 4$ & 0.7 & & & \\
\hline 12 & $27 \cdot 9$ & 0.6 & $1 \cdot 2$ & & & & \\
\hline \multicolumn{8}{|c|}{ Controls } \\
\hline 13 & 62.9 & $85 \cdot 4$ & $50 \cdot 0$ & $4 \cdot 8$ & \multirow{6}{*}{$15 \cdot 2$} & $203 \cdot 1$ & $12 \cdot 9$ \\
\hline $\begin{array}{l}14 \\
15\end{array}$ & $\begin{array}{r}89 \cdot 3 \\
228 \cdot 6\end{array}$ & $\begin{array}{r}22 \cdot 8 \\
255 \cdot 3\end{array}$ & $\begin{array}{r}1 \cdot 0 \\
171.5\end{array}$ & $\begin{array}{r}1 \cdot 0 \\
45 \cdot 7\end{array}$ & & $\begin{array}{l}114 \cdot 2 \\
716 \cdot 3\end{array}$ & $\begin{array}{l}10 \cdot 4 \\
45 \cdot 7\end{array}$ \\
\hline 16 & 180.8 & $259 \cdot 6$ & $46 \cdot 4$ & $9 \cdot 3$ & & 496.0 & \multirow{8}{*}{$\begin{array}{r}12 \cdot 0 \\
2 \cdot 2 \\
59 \cdot 4 \\
3 \cdot 3 \\
80 \cdot 6 \\
2 \cdot 6 \\
7 \cdot 1\end{array}$} \\
\hline 17 & 118.4 & $16 \cdot 8$ & $6 \cdot 4$ & 4.8 & & $146 \cdot 4$ & \\
\hline 18 & $16 \cdot 8$ & & 0.2 & $0 \cdot 8$ & & $17 \cdot 8$ & \\
\hline 19 & $24 \cdot 0$ & $12 \cdot 5$ & $3 \cdot 8$ & $14 \cdot 4$ & & $56 \cdot 6$ & \\
\hline 20 & $42 \cdot 8$ & $6 \cdot 1$ & 1.4 & 1.9 & 0.5 & $52 \cdot 7$ & \\
\hline $\begin{array}{l}21 \\
22\end{array}$ & $\begin{array}{l}46 \cdot 4 \\
18 \cdot 5\end{array}$ & $\begin{array}{r}109.9 \\
0.7\end{array}$ & 0.2 & $14 \cdot 7$ & & $\begin{array}{r}171 \cdot 0 \\
19 \cdot 4\end{array}$ & \\
\hline $\begin{array}{l}23 \\
24\end{array}$ & $39 \cdot 4$ & $24 \cdot 6$ & 1.9 & 0. & & $66 \cdot 6$ & \\
\hline & $106 \cdot 8$ & & 1.0 & $3 \cdot 8$ & & 178.0 & \\
\hline
\end{tabular}

For each case of mesothelioma a matched control was chosen from the subjects who had died of other causes. Matching was for sex, length of service, and age at death. Matching for length of service was always within four years and for age at death within three years, except for case 12, for which the control (case 24) was nine years younger. On average, year of death was also matched. The causes of death among the controls were cancer of the lung (four), cancer of the ovary, carcinomatosis, asbestosis, and five others.

For each case in the study a block was chosen based on the amount of lung tissue in the block. The block was prepared and examined, using the methods of Pooley and Clark, ${ }^{11}$ and the fibres present identified and quantified with a transmission electron microscope. During this examination no identification details were available. Initially, the samples from the 12 patients with mesothelioma and three of the controls were examined in one batch; later, the samples from the nine other controls were examined together with samples from four of the patients with mesothelioma. In these patients the second examination was of a different block to that examined earlier. In this paper attention is restricted to chrysotile and crocidolite asbestos, but other fibres including amosite were present (table II). Fibre counts were expressed in units of millions of fibres/g dried tissue.

The amounts of each type of asbestos in those dying of mesothelioma and controls were compared in terms of both the absolute fibre count and the percentage of the total fibre count. The absolute counts had distributions that were positively skewed, and transformed variables were used for analysis. The fibre counts were

TABLE III-Lung contents of those dying of mesothelioma and controls (fibre counts expressed in millions/g (and \% of total fibres))

\begin{tabular}{|c|c|c|c|c|c|c|c|}
\hline \multicolumn{4}{|c|}{ Patients with mesothelioma } & \multicolumn{4}{|c|}{ Controls } \\
\hline Case No & Total fibre & Chrysotile & Crocidolite & Case No & Total fibre & Chrysotile & Crocidolite \\
\hline 1 & $\left.\begin{array}{l}384 \\
480\end{array}\right\} 432$ & $\left.\begin{array}{l}77 \cdot 7 \\
48 \cdot 0\end{array}\right\} 62 \cdot 9(15)$ & $\left.\begin{array}{l}277 \cdot 2 \\
393 \cdot 6\end{array}\right\} 335 \cdot 4(78)$ & 13 & 216 & $62.9(29)$ & $85 \cdot 5(40)$ \\
\hline $\begin{array}{l}2 \\
3\end{array}$ & $\left.\begin{array}{l}59 \\
17 \\
59\end{array}\right\} 38$ & $\left.\begin{array}{l}6.7(11) \\
12.5 \\
19.5\end{array}\right\} 16.0(42)$ & $\left.\begin{array}{c}46.1 \\
1.2 \\
1.8\end{array}\right\} 1.5(48)$ & $\begin{array}{l}14 \\
15\end{array}$ & $\begin{array}{l}125 \\
762\end{array}$ & $\begin{array}{r}89 \cdot 3(71) \\
228 \cdot 6(30)\end{array}$ & $\begin{array}{r}22 \cdot 8(18) \\
255 \cdot 3(34)\end{array}$ \\
\hline 4 & $\left.\begin{array}{r}50 \\
121\end{array}\right\} 86$ & $\left.\begin{array}{l}21 \cdot 4 \\
43 \cdot 0\end{array}\right\} 32 \cdot 2(37)$ & $\left.\begin{array}{l}19.5 \\
57.2\end{array}\right\} 38 \cdot 4(45)$ & 16 & 496 & $181 \cdot 0(36)$ & $259.4(52)$ \\
\hline 5 & $\left.\begin{array}{r}124 \\
49\end{array}\right\} 87$ & $\left.\begin{array}{l}90 \cdot 0 \\
37 \cdot 0\end{array}\right\} 63.5(73)$ & $\left.\begin{array}{r}25 \cdot 2 \\
8.6\end{array}\right\} 16 \cdot 9(19)$ & 17 & 160 & $118 \cdot 4(74)$ & $16 \cdot 8(11)$ \\
\hline $\begin{array}{r}6 \\
7 \\
8 \\
9 \\
10 \\
11 \\
12\end{array}$ & $\begin{array}{r}25 \\
161 \\
466 \\
284 \\
38 \\
40 \\
45\end{array}$ & $\begin{array}{r}17 \cdot 2(69) \\
16 \cdot 7(10) \\
218.6(47) \\
22.4(8) \\
25.9(68) \\
24 \cdot 1(60) \\
27.9(62)\end{array}$ & $\begin{array}{r}4.5(18) \\
139.8(87) \\
86.7(19) \\
190.2(67) \\
0.7(2) \\
7.0(18) \\
0.6(1)\end{array}$ & $\begin{array}{l}18 \\
19 \\
20 \\
21 \\
22 \\
23 \\
24\end{array}$ & $\begin{array}{r}20 \\
116 \\
56 \\
252 \\
22 \\
74 \\
178\end{array}$ & $\begin{array}{r}16 \cdot 8(84) \\
24 \cdot 0(21) \\
42 \cdot 8(76) \\
46.3(18) \\
18.5(84) \\
39 \cdot 4(53) \\
106.8(60)\end{array}$ & $\begin{array}{c}0 \\
12.4(11) \\
6.1(11) \\
109.9(44) \\
0.7(3) \\
24.5(33) \\
66.4(37)\end{array}$ \\
\hline
\end{tabular}

consultant to the Manchester mesothelioma panel and two members of the EEC mesothelioma panel.

All the cases of mesothelioma were included in the study of lung contents except for one, in which there was insufficient material. Table I gives details of the work histories. Seven people had been first exposed before 1933, the year that the asbestos regulations became operative. The interval between first exposure and death was between 27 and 55 years except in one case (case 12), in which it was only 10 years. In this case the woman had been employed part time to clean the offices and may have gone into the factory area to clean the supervisors' offices. transformed to logarithms, after addition of the constant $0 \cdot 1$ since there were zero values. Patients with mesotheliomas and controls were compared using Student's paired $t$ test. Mean fibre counts were used for those patients examined twice.

\section{Results}

Table III shows the individual fibre counts for chrysotile and crocidolite. Table IV gives the average values of the amounts of 
asbestos, both in absolute terms and as percentages of total fibres. The lungs of the controls contained more chrysotile than those of the patients with mesotheliomas but this difference was not significant ( $p>0.1$ for fibre count, $p>0.05$ for percentage of total). The patients with mesotheliomas and controls had similar absolute amounts of crocidolite in their lungs, and although in percentage terms the lungs of the patients with mesotheliomas contained more crocidolite than those of the controls, this difference could easily have been due to chance $(p>0 \cdot 2)$.

TABLE IV-Mean lung contents (and $95 \%$ confidence limits) of those dying of mesothelioma and controls

\begin{tabular}{lll}
\hline & $\begin{array}{l}\text { Patients with } \\
\text { mesothelioma }\end{array}$ & Controls \\
\hline $\begin{array}{lll}\text { Chrysotile: } \\
\text { No of fibres (millions } / \mathbf{g})^{*}\end{array}$ & $29(17,51)$ & $55(30,103)$ \\
$\begin{array}{l}\% \text { of total fibres } \\
\text { Crocidolite: }\end{array}$ & $42(26,58)$ & $53(37,68)$ \\
$\begin{array}{l}\text { No of fibres (millions } / \mathbf{g})^{*} \\
\% \text { of total fibres }\end{array}$ & $17(4,68)$ & $18(4,84)$ \\
& $36(16,57)$ & $24(13,35)$ \\
& &
\end{tabular}

* For the number of fibres the calculations were carried out *For the number of fibres the calculations were carried out
on the transformed scale log (No $+0 \cdot 1)$ and then trans-
formed back to the original units.
The variability due to sampling the lung and the analytical process must be considered. Table III shows both sets of results for the four patients with mesothelioma for whom two blocks were analysed. The variation was between twofold and threefold for both chrysotile and crocidolite. The variability between individuals was much greater than this, so that in comparing the groups the sampling and analytical variability slightly decreased the precision of the comparisons but did not invalidate them. The variability would be more critical, however, if results were being used to determine an individual's exposure or for compensation purposes.

A second question is whether our study throws any light on the amount of exposure to crocidolite at this factory. This can be answered only by comparing the results with those of other studies. Groups from three other studies were chosennamely, a group of controls taken from deaths occurring in the United Kingdom in $1976^{12}$; a group of controls from six towns in the United Kingdom for whom consecutive postmortem examinations were done in $1977^{13}$; and a group of workers who were engaged in assembling gas masks containing crocidolite in the early 1940s and among whom mesotheliomas had occurred. ${ }^{14}$ Table $\mathrm{V}$ shows the median amounts of chrysotile and crocidolite in the lungs. The workers in the textile factory

TABLE $\mathrm{v}-$ Lung contents in previous studies compared with present study (median values)

\begin{tabular}{|c|c|c|c|c|c|}
\hline & \multirow{2}{*}{$\begin{array}{l}\text { No in } \\
\text { study }\end{array}$} & \multicolumn{2}{|c|}{ Millions fibres/g } & \multicolumn{2}{|c|}{$\%$ of total fibres } \\
\hline & & Chrysotile & Crocidolite & Chrysotile & Crocidolite \\
\hline $\begin{array}{l}\text { Textile factory (present study): } \\
\text { Subjects dying of mesothelioma } \\
\text { Controls } \\
\text { United Kingdom } 1976 \text { (control series) }^{12} \\
\text { United Kingdom } 1977 \text { (consecutive postmortem examinations) }^{13} \\
\text { Gas-mask workers }^{14}\end{array}$ & $\begin{array}{l}12 \\
12 \\
56 \\
94 \\
18\end{array}$ & $\begin{array}{r}25 \\
55 \\
3 \\
5 \\
17\end{array}$ & $\begin{array}{l}28 \\
24 \\
0 \cdot 14 \\
0 \cdot 04 \\
86\end{array}$ & $\begin{array}{l}45 \\
57 \\
11 \\
23 \\
12\end{array}$ & $\begin{array}{c}19 \\
26 \\
0 \cdot 8 \\
0 \cdot 1 \\
55\end{array}$ \\
\hline
\end{tabular}

\section{Discussion}

This study of lung contents failed to implicate any particular type of asbestos as being responsible for the mesotheliomas that had occurred among the factory workers. Yet asbestos is the principal cause of mesothelioma, and it is highly probable that the mesotheliomas in this factory occurred as a result of exposure to asbestos. What is the cause of this apparent discrepancy ? One possibility is the selection of samples of patients with mesotheliomas and controls. Our sample of patients with mesotheliomas from patients dying during 1964-75 included eight who satisfied the criteria for inclusion in the mortality study of the factory, ${ }^{3}{ }^{4}$ in which there were nine deaths due to mesothelioma during the period covered by our study. Therefore, our study contained most of the patients with mesotheliomas who died in the relevant period.

The situation with controls was different. The ideal control group would have been a sample of all workers at the factory, but two selective mechanisms, over neither of which was there any control, had operated to produce the group from which controls were selected: firstly, only people who had died and, secondly, only those deaths that had come to postmortem examination could be considered. Deaths for which a postmortem is carried out are not a random sample of all deaths, and this is illustrated by the 12 controls, who included four patients $(33 \%)$ with lung cancer and six $(50 \%)$ with cancers of all types. In contrast, in the mortality study ${ }^{3} 20 \%$ of the controls had died of lung cancer and $32 \%$ of cancers of all types during 1966-74. These differences are not statistically significant but suggest that deaths of asbestos workers due to causes that have been associated with exposure to asbestos are more likely to come to postmortem examination than deaths from other causes. Such a tendency would work against finding a difference in lung content between patients with mesotheliomas and controls. had about 10 times as much chrysotile in their lungs as controls from the United Kingdom. In view of the known exposure in the textile factory a difference was expected, but it should have been much greater; that it was only tenfold probably reflects elimination of chrysotile from the lungs. The textile workers had about 300 times as much crocidolite in their lungs as the subjects in the two control series: only four of the 150 controls from the United Kingdom had over 10 million fibres/g in their lungs compared with 16 out of 24 of the textile workers. The amount of dust in the lungs was not strictly comparable between the groups because sampling of the lung was standardised only in the 1976 and 1977 studies; in the other studies we had to take what was available. The relative distribution of the different fibre types is less likely to have been affected by this, and the contrast for crocidolite between textile workers and the control groups was also large for the percentage of total fibres: crocidolite fibres comprised more than $10 \%$ of the total fibres in 19 of the 24 textile workers compared with only nine of the 150 controls. The textile workers did not have as much crocidolite in their lungs as the gas-mask workers, who had been exposed to crocidolite for about two years; nevertheless, the proportion of crocidolite in the lungs of the textile workers was closer to the proportion in the gas-mask workers than to the proportions in the control groups. Therefore, the possible contribution of exposure to crocidolite in causing mesotheliomas in this textile factory cannot be ignored.

The evidence of substantial exposure to crocidolite means that these mesotheliomas cannot be attributed to exposure to chrysotile simply because this was the predominant type of asbestos in the airborne cloud to which the workers were exposed.

We are grateful to Dr D S Lyon of Rochdale Hospital for the supply of postmortem material, and to TBA Industrial Products for help over many years. 


\section{References}

1 Doll R. Mortality from lung cancer in asbestos workers. $\mathrm{Br} \mathcal{F}$ Ind $\mathrm{Med}$ 1955;12:81-6.

${ }^{2}$ Knox JF, Doll RS, Hill ID. Cohort analysis of changes in incidence of bronchial carcinoma in a textile asbestos factory. Ann NY Acad Sci 1965;132:526-35.

${ }^{3}$ Knox JF, Holmes S, Doll R, Hill ID. Mortality from lung cancer and other causes among workers in an asbestos textile factory. Br f Ind Med $1968 ; 25: 293-303$.

${ }^{4}$ Peto J, Doll R, Howard SV, Kinlen LJ, Lewinsohn HC. A mortality study among workers in an English asbestos factory. $\mathrm{Br} \mathcal{F}$ Ind $\mathrm{Med}$ 1977;34:169-73.

${ }^{5}$ Peto J. The incidence of pleural mesothelioma in chrysotile asbestos textile workers. In: Wagner JC, ed. Biological effects of mineral fibres. Lyons: International Agency for Research into Cancer, 1980:703-11. (Scientific Publications No 30.)

${ }^{6}$ British Occupational Hygiene Society. Hygiene standards for chrysotile asbestos dust. Ann Occup Hyg 1968;11:47-69.

${ }^{7}$ Berry G, Gilson JC, Holmes S, Lewinsohn HC, Roach SA. Asbestosis: a study of dose-response relationships in an asbestos factory. $\mathrm{Br} \mathcal{F}$ Ind Med 1979;36:98-112.

${ }^{8}$ Berry G, Lewinsohn HC. Dose-response relationships for asbestos- related disease: implications for hygiene standards. Part I-morbidity. Ann NY Acad Sci 1979;330:185-94.

${ }^{9}$ Peto J. The hygiene standard for chrysotile asbestos. Lancet 1978; : 484-9.

${ }^{10}$ Health and Safety Executive. Asbestos-final report of the advisory committee. Vols 1 and 2. London: HMSO, 1979.

11 Pooley FD, Clark NJ. Quantitative assessment of inorganic fibrous particulates in dust samples with an analytical transmission electron microscope. Ann Occup Hyg 1979;22:253-71.

12 Jones JSP, Pooley FD, Clark NJ, et al. The pathology and mineral content of lungs in cases of mesothelioma in the United Kingdom in 1976. In: Wagner JC, ed. Biological effects of mineral fibres. Lyons: International Agency for Research into Cancer, 1980:187-99. (Scientific Publications No 30.)

${ }^{13}$ Wagner JC, Pooley FD, Berry G, et al. A pathological and mineralogical study of asbestos-related deaths in the United Kingdom in 1977. In: Walton WH, ed. Ann Occup Hyg (Inhaled particles V) (in press).

14 Jones JSP, Smith PG, Pooley FD, et al. The consequences of exposure to asbestos dust in a wartime gas-mask factory. In: Wagner JC, ed. Biological effects of mineral fibres. Lyons: International Agency for Research into Cancer, 1980:637-53. (Scientific Publications No 30.)

(Accepted 28 fune 1982)

\section{SHORT REPORTS}

\section{Segmental necrotising glomerulonephritis with antineutrophil antibody: possible arbovirus aetiology?}

Focal and segmental glomerulonephritis occur in mesangial IgA disease and several systemic diseases, but often the aetiology is unknown. ${ }^{1}$ We describe eight patients seen over five years with a generalised illness associated with segmental necrotising glomerulonephritis. Clinical findings and the geographic distribution of the cases suggest that infection by a group $A$ arbovirus may have been an aetiological factor.

\section{Patients, methods, and results}

The patients were four men and four women aged 28-71 years. All had been ill for several weeks with lethargy, weight loss, arthralgia or myalgia, and anorexia, nausea, vomiting, or diarrhoea. Renal symptoms (haematuria, loin pain, and oedema) were present in five and respiratory symptoms (dyspnoea or haemoptysis) in four. In all cases urine analysis showed microscopic haematuria, and in most there were also granular and hyaline casts and a small amount of protein. Serum creatinine concentration exceeded $0.1 \mathrm{mmol} / 1(1.1 \mathrm{mg} / 100 \mathrm{ml})$ in seven. Chest $x$-ray films showed abnormalities in five: in three these were mild and attributed mainly to oedema, but one had widespread intrapulmonary haemorrhage and another showed diffuse infiltration "consistent with a collagen disease." In all patients the erythrocyte sedimentation rate exceeded $100 \mathrm{~mm}$ in the first hour; five had a blood leucocyte count exceeding $10 \times 10^{9} / 1$.

Routine tests for autoantibodies were negative, but all patients had in their serum a factor that stained the cytoplasm of neutrophil leucocytes by indirect immunofluorescence. Its maximum titre was $1 / 256$, and it was predominantly IgG. It stained human leucocytes of different ABO blood groups equally well, but rodent leucocytes generally were unstained, although occasionally there was some weak cross-reactivity. Usually this neutrophil staining activity disappeared within a few days of the start of treatment, but in two patients it was present 12 months later, when the disease was otherwise quiescent. A retrospective serological survey for arbovirus antibody showed titres of $1 / 20$ and $1 / 40$ for Ross River virus in seven of the eight cases, suggesting previous infection.

Renal biopsy during the initial illness showed segmental necrotising glomerulonephritis with accumulation of fibrin and frequent formation of a crescent in the adjacent part of Bowman's space. Usually 35-75\% of glomeruli were affected, but in two cases more than $90 \%$ were, while in one case fewer than $10 \%$ contained a lesion. Direct immunofluorescence showed only small irregular deposits of fibrin in damaged glomerular lobules and adjacent crescents.

All patients were treated with prednisolone $(50 \mathrm{mg} /$ day) and either cyclophosphamide ( $100 \mathrm{mg} /$ day; seven patients) or azathioprine $(100 \mathrm{mg} / \mathrm{day}$; one). Three required haemodialysis, of whom two also received plasmapheresis (seven and 10 exchanges). After follow-up for one to five years all patients were alive and well; four had some residual impairment of renal function, but none required chronic haemodialysis or renal transplantation. Recurrent disease occurred in two cases, three and five years after the onset. In both this was associated with reappearance of antineutrophil factor in the serum, and renal biopsy showed active segmental glomerulonephritis on a background of long-standing glomerular scarring. Both patients again responded to treatment with prednisolone and cyclophosphamide.

\section{Comment}

The glomerular lesions in these cases were morphologically indistinguishable from those in microscopic polyarteritis nodosa. ${ }^{2}$ Staining of neutrophil cytoplasm by these patients' sera was a characteristic diagnostic finding; this has not been previously described and has not been seen otherwise in more than 5000 sera examined during the past five years. Because of an unusual rural clustering of the cases, mainly in the Murray River valley, and the prominence of arthralgia and myalgia, this condition may be related to epidemic polyarthritis, which is common in this area ${ }^{3}$ and caused by Ross River virus. ${ }^{4}$ Serology showed evidence of previous infection by this virus in seven of the eight patients; the prevalence of serum antibodies to this virus in this region is $14.6 \% .^{5}$

Further serological investigation using $\operatorname{Ig} M$ antibody as an index of recent infection is needed to establish a causal role for Ross River virus in this form of glomerulonephritis.

We thank Dr N D Stallman of the Queensland State Health Laboratories for the arbovirus antibody studies.

1 Heptinstall RH. Pathology of the kidney. 2nd ed. Boston: Little, Brown and Co, 1974

2 Davison J, Ball J, Platt R. The kidney in periarteritis nodosa. $Q \mathcal{F}$ Med 1948;17:175-202.

3 Anderson SG, French EL. An epidemic exanthem associated with polyarthritis in the Murray Valley, 1956. Med f Aust 1957;ii:113-7.

4 Doherty RL, Whitehead RH, Gormon BM, O'Gower AK. The isolation of a third group A arbovirus in Australia with preliminary observations on its relationship to epidemic polyarthritis. Australian Fournal of Science $1963 ; 26: 183-4$.

5 Echuca-Melbourne Collaborative Group. Arbovirus infection in a Murray Valley community. Med $\mathcal{F}$ Aust 1974;i:257-9.

\section{(Accepted 26 May 1982)}

St Vincent's Hospital, Melbourne, Victoria 3065, Australia

D J DAVIES, MD, FRCPA, deputy director, department of anatomical pathology

J E MORAN, MB, FRACP, renal physician

J F NIALL, MD, FRACP, senior renal physician

Department of Anatomy, University of Melbourne, Victoria 3052 Australia

G B RYAN, MD, PHD, professor 